\title{
Waardenburg Syndrome Type 4
}

National Cancer Institute

\section{Source}

National Cancer Institute. Waardenburg Syndrome Type 4. NCI Thesaurus. Code C124842.

A rare, autosomal dominant or autosomal recessive syndrome caused by mutations in the SOX10, EDN3, or EDNRB genes. It is characterized by pigmentary abnormalities of the hair, skin, and eyes, congenital sensorineural hearing loss, and Hirschsprung disease. 